\title{
Euplectus lapponicus (Coleoptera: Staphylinidae: Pselaphinae), a new species from boreal Finland
}

\author{
Ivan Löbl \& Jaakko Mattila
}

Löbl, I. \& Mattila, J. 2010: Euplectus lapponicus (Coleoptera: Staphylinidae: Pselaphinae), a new species from boreal Finland. — Entomol. Fennica 21: 181186.

A new species of the genus Euplectus Leach, 1817, E. lapponicus sp. n. Löbl \& Mattila, is described from the North Boreal zone of Finland. The species is distinctive, and may be easily distinguished by the reduced number of elytral foveae, in combination with the size of the body, the punctation, and the genital characters.

I. Löbl, Muséum d'histoire naturelle, route de Malagnou 1, CH-1208 Geneva 8, Switzerland;E-mail: ivan.lobl@bluewin.ch

J. Mattila, Metsähallitus, Natural Heritage Services, P.O.Box 36, FI-40101 Jyväskylä, Finland; E-mail: jaakko.mattila@metsa.fi

Received 14 April 2010, accepted 7 June 2010

\section{Introduction}

Euplectus Leach, 1817 is one of the pselaphine genera associated with rotten wood of a large variety of trees (e.g., Horion 1949, Kangas 1951, Palm 1959, Pearce 1957). Some species are also found under loose bark, in leaf litter, compost, moss, in bird nests, and may be associated with ants. To date, ten of the 30 species known to inhabit Europe have been recorded from Finland (Silfverberg 2004, Löbl \& Besuchet 2004), all occurring also in the boreal zone (see Ahti et al. 1968): E. kirbii Denny, 1825 and E. nanus (Reichenbach,1816), extend north to reach the South Boreal zone, E. sanguineus Denny, 1825 and $E$. bescidicus Reitter, 1882 reach north the Middle Boreal zone, and the ranges of E. piceus Motschulsky, 1835, E. decipiens Raffray, 1910, E. signatus (Reichenbach,1816), E. punctatus Mulsant \& Rey, 1861, E. karstenii (Reichenbach,1816), and E. mutator Fauvel, 1895 extend north to reach the North Boreal zone. Euplectus species are found in the Russian boreal taiga (see
Kurbatov, 1988, 1991). According to S.A. Kurbatov (personal communication), E. gravis Kurbatov, 1988, and E. rutilans Kurbatov, 1988 were found in Russian boreal forests in addition to $E$. karstenii, E. punctatus, E. signatus, E. mutator, and E. decipiens. Euplectus karstenii and E. signatus were introduced to North America but are unknown from boreal taiga of Canada and Alaska (Chandler 1997, Davies 1991, Wagner 1975). Typically, the north European Euplectus, as are all other pselaphines, Meliceria tragardhi Palm, 1938 excepted, are widely distributed and wellknown species. Discovery of an additional Pselaphinae species from northern Europe seemed therefore improbable. Euplectus lapponicus described below shows that application of various sampling methods may lead to unexpected findings, even in habitats that exhibit low taxonomic diversity.

The identification of European Euplectus is not easy, unless characters of the male genitalia are used. The external characters given in existing keys (e.g., Jeannel 1950, Kangas 1951, Besuchet 
1974) are often not clearly defined, erroneously termed, or comparative and difficult to apply unless you have access to reliably identified species. As an example, the head width is used as a key character but usually without indication if measured with or without eyes, the vertexal impression is termed a "fovea", and expressions such as "more" and "less" are frequently used. In spite of that, E. lapponicus may be readily distinguished by its external characters.

\section{Material and methods}

The terminology follows Chandler (2001). The aedeagus of the holotype and legs and antenna of one paratype are mounted on slides in Canada balsam, and are illustrated. The aedeagi of the remaining males are mounted in Euparal. The males were dissected prior to our study and their abdominal apical segments were lost, besides one specimen. The length of the body is measured from the anterior margin of the front to the apical margin of abdominal tergite 4 in males, or 5 in females. Arabic numerals are given to exposed abdominal tergites and sternites.

The examined specimens are deposited in the following collections:

MZH: Zoological Museum of the Helsinki University, Helsinki, Finland

MHNG: Muséum d'histoire naturelle, Geneva, Switzerland

PCJM: Private collection of the second author PCEH: Private collection of Esko Hyvärinen

\section{Description of Euplectus lapponicus sp. n. Löbl \& Mattila}

Type specimens. Holotype: male, in $\mathrm{MZH}$, carded: Finland 758084:345402 Li: Inari, Allivuotso 21.VI.-20.VII.2007 Esko Hyvärinen et al. leg. Paratypes: 3 males, 2 females, with same data as the holotype. One male paratype in MHNG, one male paratype in PCJM, one male paratype in $\mathrm{PCEH}$, the remaining paratypes in MZH.

Diagnosis. Head with distinct punctation cov- ering most of frons and vertex, vertex with median carina. Posterior arms of U-shaped frontal impression shallow, indistinct but reaching tentorial foveae. Pronotum about as wide as head at eye margins, widest in anterior third. Elytra with two basal foveae. Discal carinae on tergite 1 distinct, extended beyond tergal mid-length. Male trochanters lacking obvious sexual characters. Aedeagus with fused parameres, setal patch situated on left parameral margin, apical margin deeply emarginate, apophyses absent, basal bulb weakly elongate, dorsal diaphragm small, internal sac bifid apically.

Description. Length $1.63-1.80 \mathrm{~mm}$ (males), $1.85-1.87 \mathrm{~mm}$ (females). Body uniformly rufous, antennae and femora slightly lighter, tibiae somewhat lighter than femora, palpi and tarsi distinctly lighter than femora. Pubescence short. Head in dorsal view sub-trapezoidal, $0.24-0.26 \mathrm{~mm}$ long to neck constriction $(0.27-0.31 \mathrm{~mm}$ with neck constriction), maximum width $0.31-0.35 \mathrm{~mm}$ at posterior eye margin, with eyes $0.33-0.37 \mathrm{~mm}$. Anterior margin of frons convex. U-shaped impression shallow, not clearly delimited, with posterior arms almost indistinct, reaching vertexal foveae. Centre of frons hardly convex, gradually inflexed anteriorly. Dorsal postantennal pits distinct, separated from U-shaped impression. Vertexal foveae not in impressions, about in level with eye centres, interval between them about twice as large as foveal diameter, smaller that intervals between foveae and lateral head margins. Tempora shorter than eyes, rounded. Eyes multifaceted, in dorsal view longer than genae. Vertex lacking median impression, with median carina extended to, or slightly anterior, level of posterior eye margin. Punctation dense and fairly coarse on dorsum of head, puncture diameters about as large as puncture intervals, on centre of frons punctures sparse, anterior margin of frons finely punctate. Subgenal punctation very dense and coarse, punctures narrowly separated. Antennae (Fig. 1a) with segments 1 and 2 elongate, segment 3 as long as wide, segments 4 to 8 wider than long, segments 5 and 7 each hardly larger than segments 4, 6 and 8, segment 8 slightly wider than segment 7 , following segments gradually larger, segment 11 as long as segments 8 to 10 combined and without basal stalk about 1.6 times as long as wide. Pronotum $0.30-0.34 \mathrm{~mm}$ long, 
Fig. 1. Euplectus lapponicus sp. n., male. $-a$. Antenna. - b. Mesotibia. - c. Metatibia. - d. Aedeagus, dorsal view. $-\mathrm{e}$. Aedeagus, ventral view. $-\mathrm{f}$. Aedeagus, lateral view. Scale bar $\mathrm{a}=$ $0.2 \mathrm{~mm}$, scale bar $\mathrm{b}=$ $0.1 \mathrm{~mm}$.
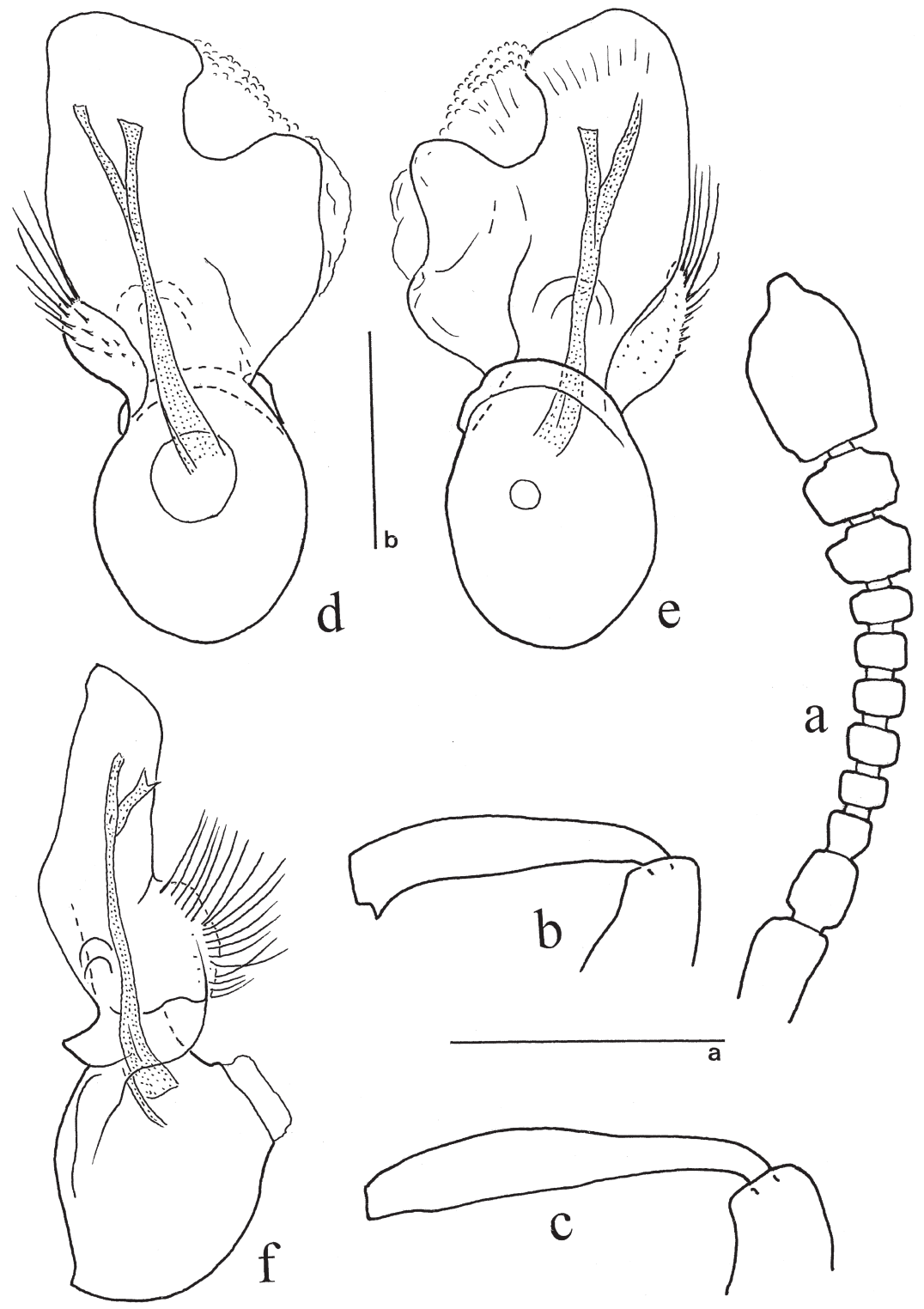

a
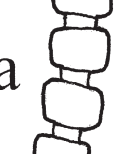

$0.31-0.36 \mathrm{~mm}$ wide, widest in anterior third, gradually narrowed basally, lateral margins arcuate, basal and apical angles widely rounded, basal margin arcuate. Median longitudinal sulcus fairly deep, hardly reaching anterior sixth of disc, joined to antebasal sulcus. Punctation fairly coarse, near base very dense, on remaining surface similar to that on prevailing dorsal surface of head, with puncture diameters about as large as puncture intervals. Prosternum with transverse wrinkles. Mesosternum impressed in middle. Metasternum with median impression starting beyond metasternal basal fourth. Elytra at suture 0.45-0.53 mm long, maximal length 0.48-0.55 $\mathrm{mm}$, widest before apical fourth, combined maximal width $0.46-0.54 \mathrm{~mm}$. Lateral margins weakly rounded. Lateral margin carinae in dorsal view obsolete or hardly visible near base. Humeral tubercles low. Each elytron with two small basal foveae similar in size, inner foveae joined to sutural stria, outer fovea joined to discal stria; anterior margin of inner basal fovea about in level with posterior margin or centre of outer basal fovea. Discal stria extended slightly beyond 


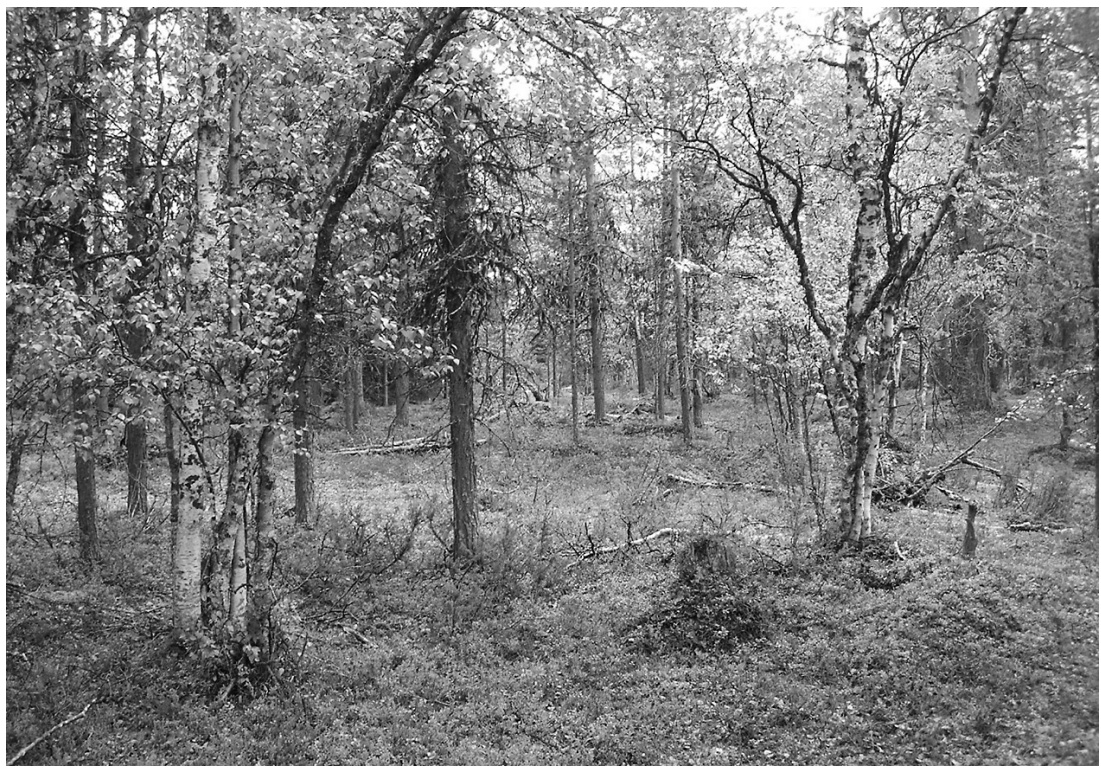

Fig. 2. Habitat of Euplectus lapponicus sp. n. in Lemmenjoki National Park, Allivuotso. elytral-mid-length, hardly visible in dorsal view, distinct in oblique view. Metathoracic wings fully developed, functional. Abdominal tergites 1 and 2 with discal carinae diverging apically, extended somewhat behind respective tergal mid-length, at bases separated by intervals about as large as fifth of basal width of tergum. Following tergites lacking discal carinae.

Male sexual characters. Mesofemora slightly inflated. Inner side of mesotibiae with small subapical denticle (Fig. 1b). Metatibiae as in Fig. 1c. Trochanters and abdominal ventrites 1 to 5 lacking obvious sexual characters. Ventrite 6 with apical margin concave, in middle $0.06 \mathrm{~mm}$ long, with shallow depression in middle, two admesal, transverse rows of peg-setae. Each row situated proximally a minute transverse ridge. Left row consisting of five blunt peg setae, right row consisting of six peg setae, five of them blunt and as in the left row, the inner peg seta narrower and pointed. Inner side of ventrite 6 with transverse apicomedian ridge. Hemisternites (morphological tergite IX) with right half concave mesally, left half sinuate mesally. Aedeagus (Figs 1d-f) $0.27-0.29 \mathrm{~mm}$ long. Basal bulb oval in dorsal view. Dorsal diaphragm small, round. Parameres fused, about 1.5 times as long as basal bulb, with remnant of left parameres distinct, bearing almost evenly long setae (lateral view), apex broadly rounded, with large emargination. Membranous structures distinct. Internal sac bifid apically, with left arm slightly longer than right arm.

Distribution. Northern Finland.

Habitat. Natural boreal forest, about $200 \mathrm{~km}$ north from Arctic Circle, close to forest border zone, on the border of the distribution of Norway spruce (Picea abies). The site is located in Lemmenjoki National Park in Finnish Lappland (lat. $68^{\circ} 18,508^{\prime}$, long. $\left.25^{\circ} 52,891^{\prime}\right)$. The elevation is rather low (290 $\mathrm{m}$ above sea level). The forest is open with canopy cover of $28 \%$ and volume of trees only $67 \mathrm{~m}^{3}$ per hectare. The volume of Scots pine (Pinus sylvestris) is $39 \mathrm{~m}^{3} / \mathrm{ha}$, Norway spruce $21 \mathrm{~m}^{3} / \mathrm{ha}$, and Downy birch (Betula pubescens) $7 \mathrm{~m}^{3} /$ ha (Fig. 2). The site is surrounded by mosaic of northern mires and forests. The specimens were collected by trunk window traps (see Hyvärinen et al. 2006).

Relationships. Euplectus lapponicus shares with E. validus a reduced number of elytral foveae, a moderately elongate basal bulb of the aedeagus with small dorsal diaphragm, a wide paramere bearing long setae at left margin, and a bifid internal sac. As these characters may be homoplasies, the closer relationships of the new species are unknown. 


\section{Discussion}

Members of Euplectus usually have elytra with four basal foveae. Euplectus bonvouloiri Reitter, 1882 may have the number of basal foveae reduced, and E. validus Besuchet, 1958 possesses only two basal foveae. E. lapponicus, which also has only two foveae at the base of each elytron, would key out in Besuchet (1974) as E. validus. E. lapponicus also shares with E. validus a moderately elongate basal bulb of the aedeagus, with a small dorsal diaphragm, parameres fused and wide, lacking apophyses, setal patch situated at left parameral margin, and the internal sac bifid apically. E. lapponicus may be readily distinguished from $E$. validus by the head behind eyes about as wide as the pronotum (while it is distinctly narrower than the pronotum in E. validus), the pronotal punctation coarser than the elytral punctation, the lateral contours of pronotum rounded (oblique near base in E. validus), and the elytra with the inner basal foveae situated close to the basal margin (in E. validus the anterior margin of the inner basal fovea is situated in or behind level of posterior margin of outer fovea). Besides, the male mesofemora are notably swollen, the mesotibial denticle is apical, and the paramere is not apically notched in E. validus.

The functional metathoracic wings in E. lapponicus provide evidence that the reduction of wings is not necessarily correlated with the reduction of the number of elytral fovea, as stated by Besuchet (1974).

The length of the discal carinae on the abdominal tergite $1 \mathrm{and} /$ or 2 is one of the key characters used by authors (e.g., Jeannel 1950; Kangas, 1951, Besuchet 1974) for identification of West Palaearctic species of Euplectus. These carinae are not clearly visible in all species and their length may vary within a species as it may appear to be different depending on the angle of observation and on optics. While these carinae extend decidedly posterior to the respective tergal midlength in E. validus, they are less clearly seen in E. lapponicus. If considered as not extending posterior to the tergal mid-length, the new species may keys out as E. punctatus in Besuchet (1974), or as E. punctatus or E. tholini Guillebeau, 1888 in Jeannel (1950).

Jeannel (1950) placed the European species of Euplectus in two subgenera, Euplectus s. str. and Diplectellus Reitter, 1909, based on the presence or absence of a vertexal "fovea" (in fact an impression at posterior margin of the vertex) and on the parameres that may be separated or fused. He (Jeannel 1956) established for the North African species two additional subgenera, Diplectidius and Euplectinus, based on the internal sac. According to Jeannel (1956), Diplectellus is defined by the bifid internal sac. In addition, Jeannel (1. c.) placed the species of these subgenera in a number of informal groups. Wagner (1975) and Chandler (1997) listed Diplectellus as a valid subgenus, and Wagner (1975) recognized informal species groups for the Nearctic species, while Karaman (1962) used only the informal species groups, and Besuchet (1974) listed Jeannel's subgenera, as a number of other genus-group names, in synonymy with Euplectus. Subsequent workers on Palaearctic Euplectus (Kurbatov 1988, 1991, Sabella 1998) ignored both, the subgenera, and the informal species groups. E. lapponicus possesses characters used to define Diplectellus, but does not provide evidence supporting the monophyly of that group, nor supports it as a valid subgenus.

Acknowledgments. Esko Hyvärinen set the window traps together with Mia Vuomajoki, Jari Kangasniemi and Petteri Polojärvi from Metsähallitus' Natural Heritage Services. JK and PP emptied the traps during the season. Esko Hyvärinen provided photographs of the site and gave comments on the manuscript. Donald S. Chandler, Durham, commented an earlier draft of the paper. Information on distribution of Euplectus in boreal Russia was kindly provided by S.A. Kurbatov, Moscow.

\section{References}

Ahti, T., Hämet-Ahti, L. \& Jalas, J. 1968: Vegetation zones and their sections in northwestern Europe. - Annales Botanici Fennici 5: 169-211.

Besuchet, C. 1974: 24. Familie: Pselaphidae. Pp. 305-362. — In: Freude H., Harde K. W. \& G. A. Lohse (eds), Die Käfer Mitteleuropas. Band 5 Staphylinidae II (Hypocyphtinae und Aleocharinae) Pselaphidae. Goecke \& Evers Verlag, Krefeld, 381 pp.

Chandler, D. S. 1997: A catalog of the Coleptera of America north of Mexico. Family: Pselaphidae. — United States Department of Agriculture, ix +118 pp.

Chandler, D. S. 2001: Biology, morphology, and systematics of the ant-like litter beetles of Australia (Coleoptera: Staphylinidae: Pselaphinae). — Memoirs on Entomology, International 15: 1-viii, 1-560. 
Davies, A. 1991: Pselaphidae. Pp. 125-129. — In: Bousquet Y. (ed.), Checklist of beetles of Canada and Alaska. Agriculture Canada, vi +430 pp.

Horion, A. 1949: Faunistik der Mitteleuropäischen Käfer. Band II. Palpicornia - Staphylinoidea (ausser Staphylinidae). Unter Mitarbeit zahlreicher Koleopteren. Vittorio Klostermann, Frankfurt am Main, xxiii + 388 pp.

Hyvärinen, E., Kouki, J. \& Martikainen, P. 2006: A comparison of three trapping methods used to survey forestdwelling Coleoptera. - European Journal of Entomology 103: 397-407.

Jeannel, R. 1950: Faune de France 53 Coléoptères Psélaphides. - Paul Lechevalier, Paris, iii + 421 pp.

Jeannel, R. 1956: Les Psélaphides de l'Afrique du nord. Essai de biogéographie berbère. - Mémoires du Muséum National d'Histoire Naturelle, Nouvelle Série, Série A, Zoologie, 14:1-233.

Kangas, E. 1951: Die finnischen Euplectus-Arten (Col., Pselaphidae). - Suomen Hyönteistieteellinen Aikakauskirja 17: 136-148.

Karaman, Z. 1962: Einige unsere Artes des Genus Euplectus (Psel. Col.). - Jahrbuch der Land- und Forstwirtschaflichen Fakultät der Universität in Skopje 15 (1961762): 155-168 [In Serbo-Croatian with German summary].
Kurbatov, S. A. 1988: Species of the genus Euplectus (Coleoptera, Pselaphidae) from the Far East of the USSR. —Zoologicheskiy Zhurnal 67: 1085-1090 [In Russian with English summary].

Kurbatov, S. A. 1991: Beetles of the tribe Euplectini (Coleoptera, Pselaphidae) from the Soviet Far East. Communication 2. - Zoologicheskiy Zhurnal 70: 55-62 [In Russian with English summary].

Löbl, I. \& Besuchet, C. 2004: Pselaphidae. Pp. 272-329. — In: Löbl I. \& A. Smetana (eds), Catalogue of the Palaearctic Coleoptera. Vol. 2. Apollo Books, Stenstrup, $942 \mathrm{pp}$.

Palm, T. 1959: Die Holz- und Rinden-Käfer der Süd- und Mittelschwedischen Laubbäume. - Opuscula entomologica Supplementum XVI, 374 pp., 47 pls.

Pearce, E. J. 1957: Coleoptera (Pselaphidae). — Handbooks for identification of British Insects 4:1-32.

Sabella, G. 1998: Pselafidi di Sicilia. - Museo Regionale di Scienze Naturali, Torino, 415 pp.

Silfverberg, H. 2004: Enumeratio nove Coleopterorum Fennoscandiae, Daniae et Baltiae. — Sahlbergia 9: 1111.

Wagner, J. A. 1975: Review of the genera Euplectus, Pycnoplectus, Leptoplectus, and Acolonia (Coleoptera: Pselaphidae) including Nearctic species north of Mexico. - Entomologica Americana 49: 125-207. 